\title{
The effects of transplanting stress on photosynthesis, stomatal conductance and leaf water potential in Cedrus atlantica Manetti seedlings: role of root regeneration
}

\author{
J.M. Guehl ${ }^{1}$, G. Aussenac ${ }^{1}$ and P. Kaushal ${ }^{2}$ \\ 1 Laboratoire de Bioclimatologie et Ecophysiologie Forestière, Station de Sylviculture et Production, \\ INRA, Centre de Nancy, Champenoux, 54280 Seichamps, France, and \\ 2 Department of Forestry and Natural Resources, Punjab Agricultural University, Ludhiana, \\ 141004 India
}

\section{Introduction}

Artificial forest stand establishment may be achieved either with container-grown seedlings or with bareroot planting stock. Since growing seedlings in containers may lead to abnormal root development after transplanting (Aussenac et al., 1988), renewed attention should be given to bareroot planting.

Bareroot transplanting is accompanied by a specific transplanting stress, that may lead to substantial plant mortality or reduced growth, due to the disturbance of the functional continuity at the soil-root interface (Sands, 1984), or to mechanical damage to roots caused by lifting the plants from the nursery beds (Chung and Kramer, 1975).

Physiological processes, such as $\mathrm{CO}_{2}$ assimilation and translocation (Stupendick and Shepherd, 1980), stomatal conductance and plant water status (Sands, 1984; Kaushal et al., 1987; Aussenac and
El Nour, 1986), considered separately, have been shown to be affected significantly by transplanting. However, a satisfactory rationale for studying effects of transplanting should also include valuable information on the possible linkages between these processes and the interrelationships with root regeneration after transplanting.

\section{Materials and Methods}

One yr old seedlings were transplanted from a nursery to a glasshouse in polyethylene bags $(16 \times 60 \mathrm{~cm})$ containing sphagnum peat and were maintained well-watered. One yr later, in October 1985, half of the plants were lifted from the bags, stored for $20 \mathrm{~h}$ at $20^{\circ} \mathrm{C}, 100 \%$ relative humidity and in darkness, and then planted again in similar bags. The other half (control plants) were maintained in the initial bags. The carbon dioxide assimilation rate $(A)$, stomatal conductance $\left(g_{\mathrm{s}}\right)$ and predawn needle water potential $\left(\psi_{p}\right)$ of these seedlings were measured just prior to transplanting (day 0 ), and 
$465 s$

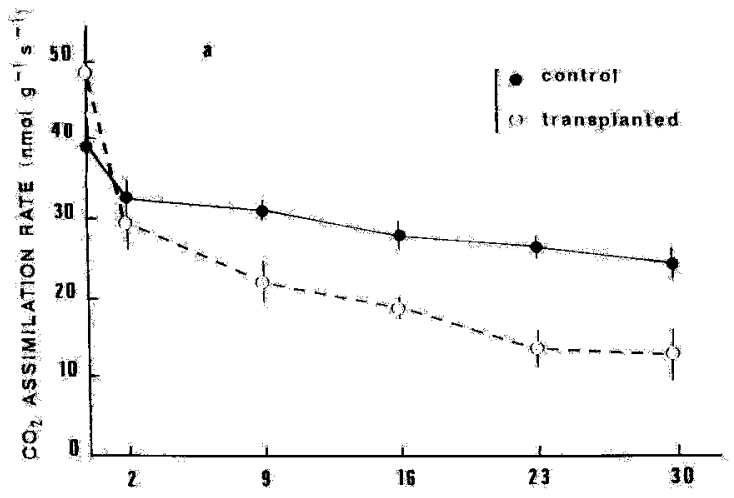

DAYS AFIEA TRANSPLANING
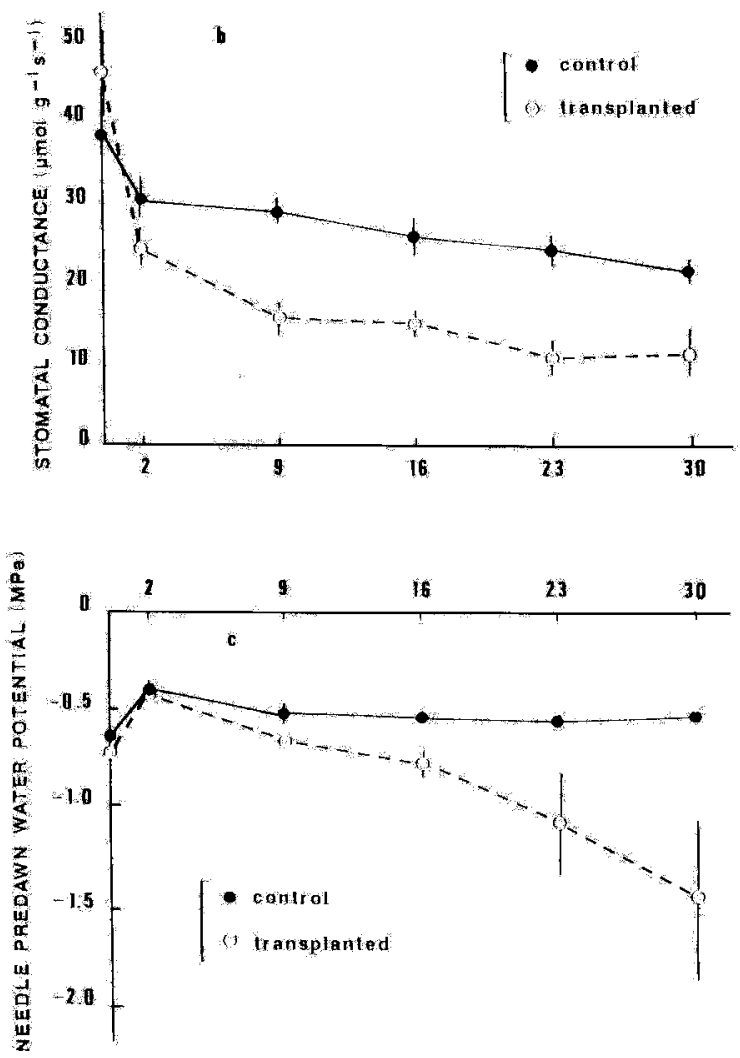

DAYS AFTER TMANSPI ANTING

Fig. 1. Concurrent time course of a, $\mathrm{CO}_{2}$ assimilation rate $(A)$; b, stomatal conductance for $\mathrm{CO}_{2}\left(g_{\mathrm{s}}\right)$ and $\mathrm{c}$, predawn needle water potential $\left(\psi_{0}\right)$ in control and transplanted Cedrus attantica seedlings. Transplanting was carried out on day 0 , after the gas exchange measurements. $n=6$; bars denote \pm 1 SEM. 
then on days $2,9,16,23$ and 30 after transplanting.

In experiment 2, seedlings were transplanted in minirhizotrons. The plants were given optimal fertilization and the root systems were maintained at $20^{\circ} \mathrm{C}$ in order to promote root regeneration. Assimilation rate measurements and root observations (number of growing roots and root elongation) were made just before transplanting (day 0 ) and then weekly from day 7 to day 49 after transplanting.

Gas exchange measurements were made with a classical open system under standard environmental conditions. In experiment 1 , intercellular $\mathrm{CO}_{2}$ concentration $\left(c_{i}\right)$ values were calculated from the $A$ and $g_{\mathrm{s}}$ data, which permits assessment of the extent to which changes of $A$ following transplanting are due to reduced diffusional supply of $\mathrm{CO}_{2}$ to the mesophyll or to decreasing mesophyll photosynthetic capacity
(Jones, 1985). In an $A$ vs $C_{i}$ plot, these 2 limitations are represented by the supply (Su) and demand (D) functions, respectively (see Fig. 2).

\section{Results}

\section{Experiment 1}

In the transplanted seedlings, a marked and parallel decline in both $\mathrm{CO}_{2}$ assimilation and stomatal conductance occurred from day 0 to day 9 after transplanting (Fig. 1a and b); afterwards the decline continued, but was less pronounced. The control plants presented a decreasing trend of gas exchange, but the decline

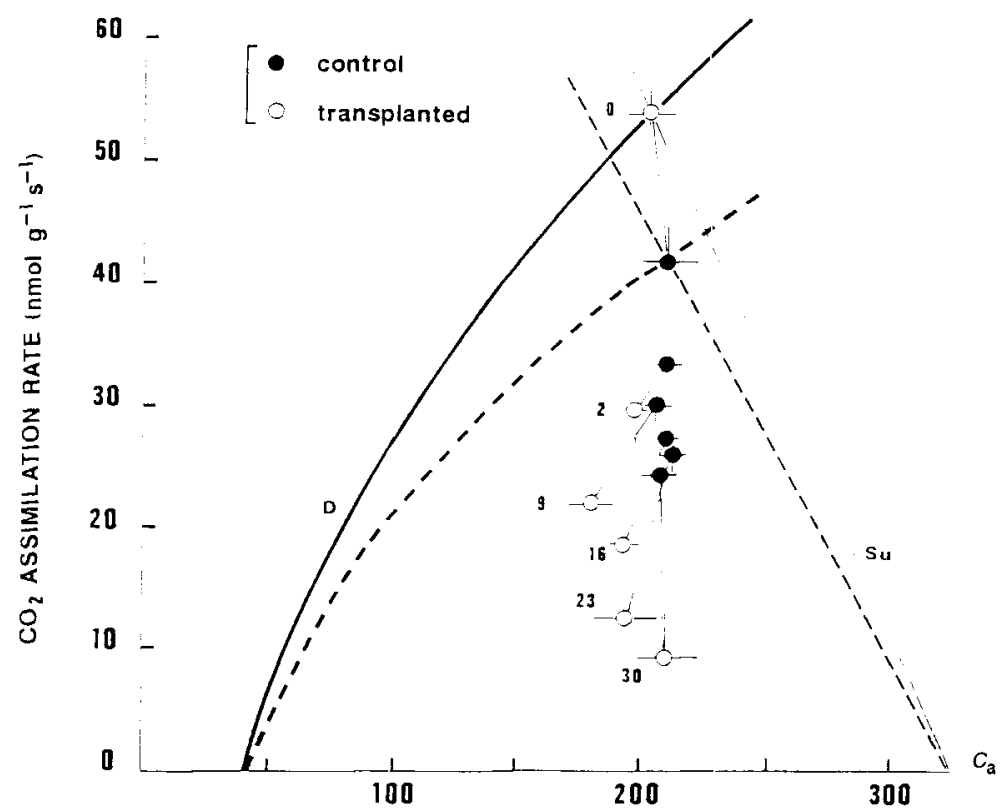

INTERCELLULAR $\mathrm{CO}_{2}$ CONCENTRATION ( $\mu \mathrm{mol} \mathrm{mol}^{-1}$ )

Fig. 2. Carbon dioxide assimilation rate $(A)$ versus intercellular $\mathrm{CO}_{2}$ concentration $\left(c_{i}\right)$ in the control and transplanted plants from day 0 (before transplanting) to day 30 after transplanting. The photosynthetic $\mathrm{CO}_{2}$ demand $(D)$ and supply $\left(S u\right.$ ) functions have been reported only for day $0 . C_{a}$ is the ambient $\mathrm{CO}_{2}$ concentration. $n=6$; bars denote \pm 1 SEM. 
was significantly less pronounced than in the transplanted plants. Predawn needle water potential (Fig. 1c) was affected by transplanting, but significantly lower values than in the control plants occurred only after day 9 . The severe decline in $A$ for the transplanted plants was accompanied by an almost constant $c_{i}$ (Fig. 2), thus indicating that, despite the parallel evolution of $A$ and $g_{s}$, the changes in Awere mainly due to an alteration of mesophyll photosynthetic capacity.
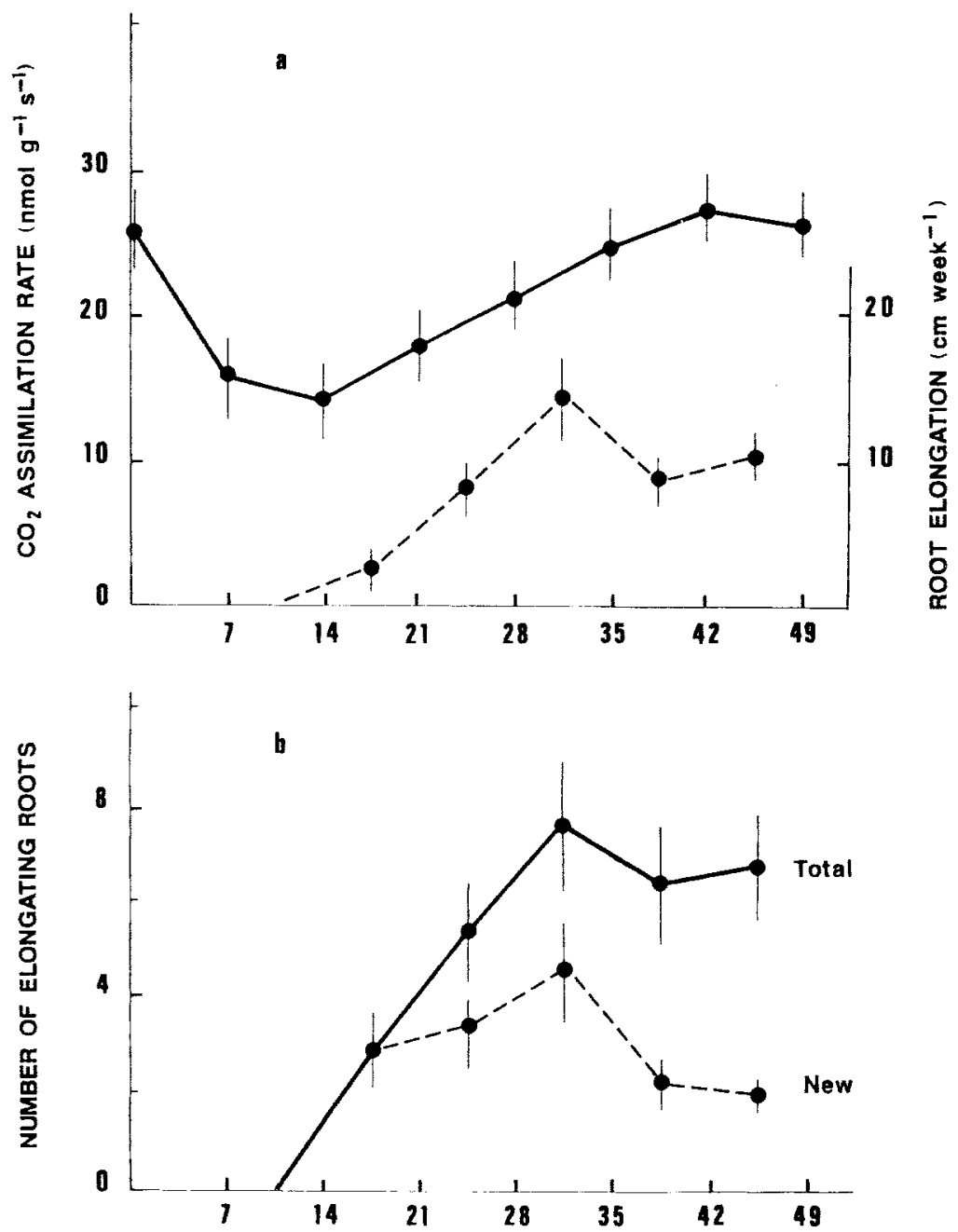

DAYS AFTER TRANSPLANTING

Fig. 3. Concurrent time course of: a, $\mathrm{CO}_{2}$ assimilation rate ( $A$, solid line) and root elongation (dashed line); and $b$, number of new and total elongating roots after transplanting. $n=15$; bars denote \pm 1 SEM. 


\section{Experiment 2}

Carbon dioxide assimilation $A$ markedly and gradually decreased after transplanting from day 0 to day 14 (Fig. 3a), and then, from day 14 to day 42 , recovered its initial value. The start of recovery in $A$ was concomitant to the beginning root regeneration (Fig. 3).

\section{Discussion}

The results of this study support the previous findings of several authors showing that $A$ (Stupendick and Shepherd, 1980), $g_{\mathrm{s}}$ and $\psi_{\mathrm{p}}$ (Sands, 1984; Aussenac and El Nour, 1986) are affected by transplanting stress.

However, the decline of $A$ due to transplanting was not a consequence of reduced $g_{\mathrm{s}}$, but was primarily determined by alterations of mesophyll photosynthesis. This, plus the parallel time course of $A$ and $g_{\mathrm{s}}$, might even suggest that reduced $g_{\mathrm{s}}$ is the consequence of altered mesophyll photosynthesis.

Leaf water status is not the factor responsible for the initial decline of $A$ and $g_{\mathrm{s}}$, but it is likely to be a relevant physiological constraint. The (common?) signal that triggers the initial decline in $A$ and $g_{\mathrm{s}}$ remains unknown (nutritional, hormonal?).
Recovery of $A$ was strictly concomitant with root regeneration, but no evidence could be found to ascertain whether a functional linkage exists between these 2 parameters, or whether they respond to a third, still unknown, factor.

\section{References}

Aussenac G. \& E:I Nour M. (1986) Evolution du potentiel hydrique et du système racinaire de jeunes plants de cèdre, pin laricio de Corse et pin noir plantés à l'automne et au printemps. Ann. Sci. For. 43, 1-14

Aussenac G., Guehl J.M., Kaushal P., Granier A. \& Grieu P. (1988) Critères physiologiques pour l'évaluation de la qualité des plants forestiers avant plantation. Rev. For. Fr. 40, 131-139

Chung H.H. \& Kramer P.J. (1975) Absorption of water and $32 \mathrm{P}$ through suberized and unsuberized roots of loblolly pine. Can. J. For. Res. 5, 229-235

Jones H.G. (1985) Partitioning stomatal and non-stomatal limitations to photosynthesis. Plant Cell Environ. 8, 95-104

Kaushal P.K. (1987) Analyse écophysiologique des effets de stress liés aux transplantations des arbres forestiers. Thesis, University of Nancy, France

Sands R. (1984) Transplanting stress in radiata pine. Aust. J. For. Res. 14, 67-72

Stupendick J.A.T. \& Shepherd K.R. (1980) Root regeneration of root-pruned Pinus radiata seedlings. II. Effect of root pruning on photosynthesis and translocation. New Zealand J. For. Sci. 148-158 